NEW LITERARIA-

An International Journal of Interdisciplinary Studies in Humanities

Volume 2, No. 2, July- August, 2021, PP. 50-56

ISSN: 2582-7375

DOI: https://dx.doi.org/10.48189/nl.2021.v02i2.007

www.newliteraria.com

\title{
The Disease Called Fear: Reading Narayan Ganguly's Short Story "Pushkara"
}

\author{
Subhajeet Singha
}

\begin{abstract}
The fatal shadow of an all-pervasive epidemic may have become a distant memory for our generation because modern medicine and therapy have progressed and our longevity is blessed. Along came Corona virus and the proverbial world of our knowledge went through chaos. We witnessed a new threat along with the microscopic virus- the banality of posttruths. This fear rapidly gets transmitted into the psychology of everyone. And how that fear can infiltrate the common judgement of populace, is the focus of this paper through reading Bengali novelist Narayan Gangopadhyay's short story, Pushkara. The story is set against the cholera epidemic in rural Bengal, where a priest prepares for a midnight Kali Puja at the cremation ground to ward off the evil of Cholera. The offal offered at the altar is consumed by a local vagrant woman, but the intoxicated and hyper tensed priest and his acolytes assume the woman in the dark to be the corporeal form of the goddess itself. Out of abject psychosis, a divine myth is born. Death and disease mark our existence as Susan Sontag called our duality as realm of night and realm of well-being. To attain the realm of well-being, we are often seen to give in to sad repercussions to mete out our existential dread. This essay will show how that fear is no less powerful than the disease itself.
\end{abstract}

Keywords- Epidemic, Existentialism, Psychoanalysis, Fear, Divinity.

“And Darkness and Decay and the Red Death held illimitable dominion over all." (Poe, 2006, p.42)

The entire corpus of human history shares a common thread. Whenever our civilization is threatened to be extinct, be it an epidemic, a war, an apocalypse upon us, all our existence is laced with a certain fear and fear knows little logic. Similarly, in this celebrated short story by Edgar Allan Poe, The Masque of the Red Death, the fateful Prince ordered his castle to be shut from inside, so that the notorious 'Red Death' may not claim lives at its whim. But his impressive plan fails miserably with the definitive victory of the epidemic and the subsequent death of all the known living beings. But why does the prince partake in such endeavour to lock his flock in isolation, and not trying to find a cure for the dreadful disease? The answer is probably that fear, abject and hopeless fear which the Pestilence stirs in us, making the mind muddier and judgment cloudy.

The situation we witnessed now, inside this virus pandemic in 2020 A.D., is a torrent of fabricated information to be poured over us, helpless and anxious wait for a possible cure, extremely polarized debates over the use of preventive measures, failure of governmental policy in wake of such an unforeseen global catastrophe and the rise of a new threat along with the microscopic virus- the banality of post-truths. That fear grows and the idea of posttruths gnaws at our better judgment slowly and steadily. And how this fear affects the creative imagination of a gifted story-teller, is the focus of this paper till the end. 
Mary Midgley (2001) writes, "As is well known, fear is 'natural' in the sense of having plain, substantial psychological causes" (p. 80). This is quite simple observation that fear for anything or anyone is firmly implanted in our psychology than we try to comprehend. Fear is a powerful impetus and often unknowingly we attribute kind of a negative sense to our fearful actions. But according to Midgley (2001), "In short, if somebody presses the crude question whether fear is a good or bad thing, we can only give an indirect answer- an answer which may look evasive, but is absolutely necessary in dealing with such a crude question" (p. 81). Our own dilemma is quite similar to her delineation of the psychological evaluation of fear. But she further makes an important observation on the fact,

Fear is all right in moderation. There should be neither too much nor too little of it...It involves fearing the right things, not the wrong ones, and fearing them as much as, not more than, their nature calls for. It involves understanding what are suitable objects for fear, and what kind of fear is suitable for them. (Midgley, 2001, p.81)

Now, coming back to our present question, where a threat like an alarming epidemic is precariously closing in, how far the people can be afraid of? Literature has no dearth of examples where the footprint of epidemic is still afresh. From Defoe's prominent work Journal of the Plague Year (1722 A.D.) to C. C. Humphrey's more recent historical thriller Plague (2014 A.D.), both of them etch out the vivid horror of the Black Plague in London during 1665 A.D. But look at the year of publishing for these two books, almost three hundreds of years between them; still they are connected by one common thread of fear, the fear of death. Now, epidemic and literature are not two distant relatives but neighbours who share the common quarters. Our history is laden with terrible examples of worst epidemics, like the Plague in Athens (430 B.C.), Plague of Cyprian (250-271 A.D.) or the Black Death (1346-1353 A.D.). Frank M. Snowden (2019) writes,

A second reason for concentrating on epidemic diseases is historical. Since our interest here is history, it is important to stress that, throughout human history until the twentieth century; infectious diseases have been far more devastating than other categories of illness. Indeed, globally they remain leading causes of suffering and death. One of the goals of Epidemics and Society is to explain this feature of the history of human disease. (pp. 2-3)

And he further asserts the indelible mark of epidemic on our psychology and shows how it is remarkably different from the other chronic diseases,

To have severe heart disease, for instance, can be a frightening, even lethal, experience; however, it is qualitatively different from being diagnosed with HIV/ AIDS or being stricken with smallpox, polio, or Asiatic cholera. Correspondingly, major chronic diseases such as cancer have a devastating effect on health-care systems, on the economy, and on the lives of millions of people. But unlike some epidemic diseases, heart disease and cancer do not give rise to scapegoating, mass hysteria, and outbursts of religiosity, nor are they extensively treated in literature and art. Diseases, in other words, are not simply interchangeable causes of morbidity and mortality. Epidemic diseases have left a particular $r$ legacy in their wake. Their singularity merits attention. (Snowden, 2019, p. 2)

The 'singularity' that revolves around epidemic is the reason behind such large-scale representation of literature which deals with the empire of fear among us. Snowden talks here about the reflection of staunch religious and sociological beliefs to infiltrate as well as compromising the normalcy of the behaviour for the masses when an epidemic sets in. Literature has portrayed that corruption of body and soul throughout ages. Even Bengali literature consists of many examples of epidemic creating havoc and wreck in the lives of individual as well as society. To begin with, we can mention Bankimchandra Chattopadhyay's eponymous novel Anandamath which begins with the inhuman descriptions of rural Bengal lying in complete waste in the wake of infamous famine in Bengal (year 1176 in Bengali calendar) during1876-78 A.D. But the famine resulted in gross 
malnourishment in the underprivileged section of the masses. Small pox epidemic spreads like sweeping-broom wafting away the last brittle of dust from existence. Udaychand Das shows us that Bipinchandra Pal wrote in his autobiography, Sottor Bochor (Seventy Years), that every year during the month of Chaitra and Baisakh (April-May, according to Gregorian calendar) Cholera is a recurring phenomenon in Srihatta (Sylhet, now in Bangladesh) (Das, 2020). Even Rabindranath Tagore in his autobiography, Jiban Smriti (My Boyhood Days) replicates the fear of Dengue epidemic, where he wrote that they had to escape to Chatubabu's country house at Penety (Panihati, a sub-urb on the northern fringes of Kolkata) when the dengue epidemic broke out in Kolkata. (Thakur, 1989)

In Sharatchandra Chattopadhyay's novel Shrikanta we also observe the advent of small pox epidemic in Rangoon (now Yangon in Myanmar). The protagonist Shrikanta undertakes the journey to Rangoon by ship and after embarking there he finds that the whole city is in the grip of plague. Insanitary and congested housing quarters ('bustee' or slums to be precise), lack of food or medicine and helplessly waiting to be dead in convulsion- they all constitute the ghastly details of macabre death in that particular episode in Shrikanta. Sharatchandra himself went to Rangoon in early days of 1903 A.D. where he took a job in Burma. So, it might be not far-fetched if we assume that the incident of Shrikanta's futile nursing of Manohar Babu could be the author's own tragic experience there (Das, 2020). Dineshchandra Sen who wrote Brihat Banga (Greater Bengal), a monumental work on the history of Bengal, showed us the effects of Cholera epidemic in Dhaka during 1881 A.D. Only the dismal and sudden cry of Bolo Hari (in the name of Lord Hari or Vishnu) along with wailing and intermittent shouts of orphans fill the streets of the city. The sweet chant of the name of Lord Vishnu seems like roll of thunder to the ears (Das, 2020). The British Raj paid little heed to the conditions of the victims though. In some of the Bengali texts the reference to epidemics can be traced like an annual phenomenon, which seems like a cohabitational clause between people and microbes, causing diseases. Shibnath Shastri's novel Jugantar (Epoch) in 1895 A.D., Tagore's novel Gora, Sharatchandra's novel Panditmoshai (Pundit), Bibhutibhusan Bandopadhyay's Aranyak (Of the Forest)- all these novels are exemplary classics of Bengali literature. But what connects them together? All of these tales somewhere tell the story of hopeless and helpless surrender to the goddess of epidemic.

Goddess Shitala and Sasthi have always been considered as the residing deities to be worshipped during epidemics. They are the divine entities to be recalled during emergencies and always have been put upon the high pedestal of recuperation and regeneration. Like them, goddess Manasa is considered as the deity to be worshipped if there is a case of snake bite. Most of these deities are not an integral part of Hindu canon of divine lineage. They are more like regional and folk deities, like Banbibi and Raja Dakshin Ray from the mangroves of Sunderban. In one of the short stories by Bibhutibhusan Bandopadhyay, named Rankini Debir Kharag (Scimitar of Devi Rankini), we get acquainted with the goddess Rankini, who is a presiding deity over a remote hamlet, named Chero in Santhal Parganas, somewhere probably in the state of Jharkhand now. In the story, it is believed that the holy scimitar in the hands of Devi Rankini becomes smeared with blood before the breaking out of epidemic. The local villagers used to worship the goddess in abject fear, but the narrator somehow discovers it in the end that the besmirching of the holy scimitar with blood is never a sign of the wrath of the goddess. Rather it forewarns us of the coming cataclysmic event. The naive peasant folks of the village believe it to be unholy but after the breaking out of cholera and witnessing the scimitar becoming red the narrator comes to this conclusion (Das, 2020). Narayan Gangopadhyay's short story Pushkara deals with another such tale of the goddess during the wake of epidemic.

Narayan Gangopadhyay, whose actual name was Taraknath Gangopadhyay, was a great story-teller in Bengali. Most of us may know him as the creator of Tenida- his immortal character like Jeeves or Wooster from Wodehouse's pen is famous for his antiques and mischiefs. Narayan Gangopadhyay was born in February, 1918 A.D., but this information is 
controversial as his biographer Saroj Datta cited at least three probable dates of his birth which befuddle us more. (Majumdar, 2018) Later on Narayan became a very popular professor of Bengali literature at Calcutta University beside an illustrious literary career of his own.

The short story which will be discussed here is Gangopadhyay's Pushkara. It was published in 1952, in the collection of stories called Dushasan. The time of composing the story is very much interesting. It was written just after the Independence and the trauma of partition; the Great Bengal Famine of 1942-43 A.D. and subsequent large scale Cholera epidemic have swept through the Bengal. Saradindu Bandopadhyay's short story Raater Atithi (The Night Guest) describes the advance of cholera in a supernatural atmosphere. Pushkara consists of the same gothic elements but the truth would be dawned on at the end of the story and that revelation shocks us and does not leave from our inner psychology. The word 'pushkara' in the title also refers to a certain ominous constellation of stars in the sky. The constellation is known as bhagnapadnakkhatra and bhadratithi is the name of the day when an ancient curse is awakened called 'pushkara'. It brings death and destruction in its wake and mostly brings epidemic with it. The title of the story inclines heavily towards the evil presence of a curse and the haunted setting of the story is presumed even before the opening of the story.

The story begins with the adequate paraphernalia of the preparation of a 'Swasan Kali Puja' or worshipping the form of goddess Kali who is the presiding deity of the Hindu cremation grounds. The village cremation grounds are often the place for picturesque horror. The opening paragraph of the story describes how a glorious moonlit evening of Ashwin (month of September-October in Gregorian calendar, auspicious month of Durga Puja for Hindus) has turned itself into a murky, overcast night with little breeze by this cremation ground near the river, far out in the wilderness, away from villages, as if it reflects an impending evil to reveal itself. Only the priest, named Tarkaratna, is seated in this wasted heath and is shivering from 'holy dread'. There has been an epidemic in the wake and the people of local villages have organized this 'Swasan Kali Puja' to appease the angry goddess so that the death wave may be prevented. (Gangopadhyay, 2013)

The worshipping and offering have been done with and the people of the village have left the ground, leaving behind Tarkaratna and Kashi Kumor (the potter who made the clay idol of Kali) at the place of puja. They are waiting, waiting for a premonition to happen. The offerings to the goddess, 'luchi ar pantha-r mangsho'(wheat pancakes and cooked mutton), is kept there to be devoured by the nocturnal jackals or dogs of the cremation grounds, which is the sign of the goddess' acceptance of the offering. Tarkaratna is crying out loud in vain to the goddess in between, "Devi, prasidh, devi, prasidh" (accept the offering, o! goddess). This divine process of goddess' acceptance of prasad is referred here as 'shibabhog' (devoured by jackals). (Gangopadhyay, 2013)

The description of the cremation ground is bone-chilling and dismal. The river beside the ground is shallow and extremely sedimented. A host of ghastly remnants float on its muddy water, like half-charred human remains, skulls, embers from the funeral pyre, broken clay pots, torn clothing, burnt wood and others. (Gangopadhyay, 2013) The ground is spread about in three miles of adjacent land and annually the border of the ground is earmarked differently as the river brings flood and the topography of the land is redistributed. The vignettes of the rural cremation ground prepare us for the ironical conclusion of the story.

Tarkaratna calls for her goddess in vain, as no animal comes near the offering, in guise of the goddess' acceptance. His fear amounts largely as the incompletion of 'shibabhog' will result in the enactment of 'pushkara' or the curse of death and destruction. The night goes on, the only sound that accompanies the priest is the occasional howling of dogs and jackals and the stifling sense of approaching doom. In his afflicted terror he rebukes Kashi Kumor, when Kashi raises his own doubt, that the jackals have their fresh supply of human corpse now because of the epidemic. People are escaping to safety and leave their 
dead ones behind, often without performing any final rites. The bodies are kept for the feast of the animals and it is most unlikely that they would return to the scene to gobble a few "chimes luchi ar poa-tak bokapantha-r mangsho" (dried and stale wheat pancakesand few hundred grams of cooked mutton chunks) (Gangopadhyay, 2013) Tarkaratna becomes furious at this serious accusation of his inability to summon the goddess to his offering but the sense of fear creeps in him, the fear of failure as well as the fear of the curse setting in. He looks at the clay idol of the goddess, which is not an ordinary one. The black paint is still wet and it is dripping on the Shiva idol. It seems like blood dripping from the idol. The wafting breeze brings in the decomposing odour of the dead bodies, yet no jackal comes near the offering. Tarkaranta's mind is getting more and more confusing and terrified.

The story takes an unforeseen turn, when Tarkaratna realizes there is 'something' appeared out of nowhere to accept the offering. He can hear the harsh and grating sound of teeth gnawing at the mutton. A dark apparition is devouring the offering using two hands and its eyes are burning in the dark (Gangopadhyay, 2013). The idea of using 'two hands' baffles him, but at the same time his "heat oppressed brain" (Shakespeare, 1951) conjures up a horrible image in his subconscious, like Macbeth imagining the bloody dagger in front of him. He sees a half-naked feminine figure, flowing dark hair, silhouetting after the dark overcast backdrop- crunching the bones from the meat and laughing maniacally. Tarkaratna presumes it is not those nocturnal animals, totems of the goddess, but Kali herself has appeared in corporeal form to accept the offal. The figure escapes from sight after Kashi Kumor comes into his senses from his marijuana infusing trance, listening the hysterical, blood congealing laugh. Tarkaranta's puja, his dedication and his sacrifice have become efficacious. People of the village come in throngs to witness the marvel and to listen to the birth of goddess to the earth. Tarkaratna's fame as the priest reaches to a new dimension. Here, a close parallel can be drawn between Pushkara and Shibram Chakraborty's short story Devata r Janma (Birth of God). In this short story, a mere physical phenomenon of finding a rock by the narrator turns out to be a comical yet significant study of human psyche. The 'rock' was upgraded into divinity by general superstition.

The brutal truth is revealed at the far end of the story, when Tarkaratna returns from the village in a cart. The cart is laden with precious gifts from the villagers as they are assured that 'pushkara' has been prevented. Balai Ghosh, the leader of the village-folks, offers him a hefty sum of money. Tarkaratna returns with pleased mind and sufficient purse when his cart driver notices a vagrant woman, half naked and malnourished, is lying on the ground, writhing from the death pangs, moments before a beastly death from convulsion of Cholera. Tarkaratna's cart passes by the moribund woman and the priest is too afraid to linger there as the death is contagious. Little does he know that the dark apparition from the last night is no other than this woman? The curse of 'pushkara' is lifted not by his dedicated summons and Sanskrit mantras but by the insatiable hunger of that ill-fated woman. Like the Lord Shiva accepting the poison during the 'samudramanthan' (churning of the sea, mentioned in Hindu Mythology), this woman has soaked up the beliefs and divine loyalty of the people as well as priest by consuming the 'prasad' and dying subsequently of cholera, getting rid of the poison of epidemic and disease. She is the goddess here.

The irony of the tale lies like the sting of the scorpion, at the end. The mass appeal and prayers to the goddess, led by Tarkaratna, are never answered truly. The fear of a looming epidemic, the eerie and preternatural atmosphere of the cremation ground- they all refer to our dark subconscious. We always look to find solace in the fact 'everyone dies', but do we easily consider ourselves to be included as 'everyone' in that phrase? Ullrich Hasse and William Large (2001) write,

This is not to say that Blanchot disagrees with Heidegger's analysis of our repression of death by means of its abstraction, as when we think it a banality that 'everyone dies'. But dying is this movement where I can no longer push death away from me by attributing it to 'everyone'... (p. 53)

Maurice Blanchot's idea of death as an 'impossibility of being' affects us to the core. We 
can philosophize by repeating 'everyone dies' wherever it suits us, but when it is pointed to me, when 'I' is the target of death, Blanchot affirms that the subconscious takes refuge to wired reactions. Sometime those reactions can be as meaningless as assuming the half-naked, ribs protruding, disheveled figure of a vagrant woman to be the goddess. Then again if the countrymen are suffering from hunger and disease like never before, the goddess should look like exactly such as Narayan Gangopadhyay has depicted her here.

Jo Winning in his essay, Trauma, Illness and Narrative in the Medical Humanities refers to philosopher Susan Sontag while describing about our everyday fear about death and diseases. Jo Winning (2020) says,

Such a repudiation of the yoking of trauma and illness in everyday life would seem to run contrary to the predominant narratives of pain and illness that have abounded in Western cultures for millennia. In her seminal exploration of the ways in which the discourses of Western culture deploy metaphors of disease to fend off the ubiquity of its experience, Susan Sontag describes illness as "the night side of life", a "kingdom" unique and separate from the "kingdom of the well" (Sontag 1978: 3). Despite the fact that we all prefer to dwell there, Sontag attests commonsensically that we hold "dual citizenship" in both domains (3). Our repudiation of this bilocatedness is due in part to the "lurid metaphors with which [the kingdom of the ill] has been landscaped" (4). For the purposes of this chapter, which examines trauma, illness and its literary representation in written narrative, Sontag usefully links disease and illness... (p. 266)

This 'dual citizenship' is the focus of this paper too. The kingdom of well-being is represented in this story by Tarkaratna, Balai Ghosh, Kashi Kumor, Keshab Dhuli and other villagers. They are subjected to the empire of fear. Beside the physical ailment of Cholera, the growing illness among these people is the despicable disease of fear, which Sontag refers as 'the night side of life' from the quoted text. As long as we separate ourselves from this side of life or we fail to recognize ourselves as everyone from the phrase 'everyone dies', our fear will be cloaked under the worship of the pseudo-divinity and from each such drop of dreadful fear a new god will be born.

As in Shibram Chakraborty's story Devata r Janma, the narrator of the story uproots a small circular stone from his doorway. The stone has an uncanny semblance to a Shivalinga, the powerful symbol of Lord Shiva in Hindu mythology. The narrator throws away the stone but some people of the locality take it from there and establishes as a holy relic under a tree. At first the relic does not attract much attention but its promotion to sudden divinity excites the narrator. He feels the pride of a father at the occasion of the baptizing of the stone as divine being. The sense of amusement and satire takes an ironical twist when there is a sudden outbreak of Cholera in the city. The narrator is seen at the end of the story to worship the stone which now has gathered enough devotion and dedication from the local people and they have erected a shrine to its honour (Chakraborty, 1993). People are bowing before the almighty Shiva-linga in hope of a cure. Even, in this story the fate of people is shown to be hung upon faith but in reality, this is not faith, rather the terror of the holy. Like those simple village-folks and Tarkaratna from Pushkara, the narrator from Devata r Janma nourishes a great fear whenever an impending death is looming large. The faculty of reasoning and thinking always goes into regression when the disease of doubt and fear sets in. The deaths caused by Cholera are tragic, but the death of that vagrant woman is not only tragic, it is something more. It is the mark of our indelible, incomprehensible fear in the face of catastrophe. Is there any cure for fear for death? Perhaps there is, as Shelly Kagan (2012) writes, "Recall Tolstoy's Death of Ivan Ilyich. The people in the Tolstoy story seem to have put the fact of mortality out of their mind. Why? Presumably because they think that facing it is just too crushing and overwhelming" (p. 284). That sense of "crushing and overwhelming' fear is the thread that connects us all in every pandemic, even in 2020 A.D. 


\section{References}

Chakraborty, S. (1993). Srestha Galpa. Nabapatra Prakashan.

Das, U. (2020). Mahamari O Bangla Akhyan. Korak Sahitya Patrika: Bishay Mahamari, Sharad Sankhya, pp. 273-300.

Gangopadhyay, N. (2013). Galpa Samagra. Mitra O Ghosh.

Hasse, U, \& Large, W. (2001). Maurice Blanchot. Routledge.

Kagan, S. (2012). Death. Yale University Press.

Majumdar, M. (2018). Narayan Majumdar: Jibankatha. In T. Bhowmik (Ed.), Narayan Gangopadhyay: Mastermoshai (pp. 135-148), Korak.

Midgley, M. (2001). Wickedness. Routledge.

Poe, E. A. (2006). The Portable Edgar Allan Poe. Penguin.

Shakespeare, W. (1951). Macbeth. Arden Shakespeare.

Snowden, F. (2019). Epidemics and Society: From the Black Death to the Present. Yale University Press.

Thakur, R. (1989). Rabindra Rachanavali. Visva Bharati.

Winning, J. (2020). Trauma, Illness and Narrative in the Medical Humanities. In C. Davis and H. Meretoja (Eds.), The Routledge Companion to Literature and Trauma (pp. 266-274), Routledge.

\section{Bio-note}

Subhajeet Singha is an Assistant Professor in the Department of English of Deshapran Mahavidyalaya, Purba Medinipur. He has completed his M.A. and M.Phil in English Literature from Rabindrabharati University. His areas of Interest are Postcolonial Literature and Theory, Cultural Theory, 19th Century Bengal Renaissance, Graphic Novels, Historiography. He has contributed chapters in edited volumes as well as articles in journals on Bengal Renaissance, Graphic Novels, and Cultural Studies.

Email id: subhajeet112singha@gmail.com. 